\title{
Anticancer, Antimicrobial and Antioxidant Activities of the Essential Oils of Some Aromatic Medicinal Plants (Pulicaria inuloides-Asteraceae)
}

\author{
Nabil Qaid M. Al-Hajj ${ }^{1,2}$, Algabr MN³ ${ }^{3}$ Khamis Ali Omar ${ }^{1}$, Hongxin Wang ${ }^{1, *}$ \\ ${ }^{1}$ School of Food Science and Technology, Jiangnan University, Wuxi 214122, P.R. China \\ ${ }^{2}$ Marine Science and Biological Research Authority, Aden, P.O. Box-1231, Aden, Yemen \\ ${ }^{3}$ Hajjah University, Department of chemistry, Faculty of Applied Science, P.O. Box 80004, Yemen \\ *Corresponding author: alwossabi2007@yahoo.com
}

\begin{abstract}
Purpose: To determine the anticancer, antimicrobial and antioxidant activities of Pulicaria inuloides essential oil (PiEO). Methods: 3-(4, 5-dimethylthiazol- 2-yl)-2, 5-diphenyltetrazolium bromide (MTT) was used to assess cytotoxic activity. Steam distillation of the aerial parts of $P$. inuloides was performed using a Clevenger apparatus. Antioxidant activities were determined by using 2, 2-diphenyl-1,1-picrylhydrazyl (DPPH). Disc diffusion and microtiter broth microdilution assays were employed to determine antimicrobial activity. Results: PiEO inhibited six tested strains of Listeria with minimum inhibitory concentrations of $5.49 \mu \mathrm{g} / \mathrm{mL}$ against L. monocytogenes, L. innocua, and L. ivanovii; $6.24 \mu \mathrm{g} / \mathrm{mL}$ against $L$. welshimeri, and L. grayi; and $11.55 \mu \mathrm{g} / \mathrm{mL}$ against $L$. seeligeri. PiEO also possessed more efficient free radical scavenging activities than butylated hydroxytoluene (BHT). PiEO possessed significant anticancer properties, indicated by growth inhibition and changes in the morphological structure of MCF-7 cancer cells treated with PiEO.
\end{abstract}

Keywords: Pulicaria inuloides, essential oil, MCF-7, antimicrobial, antioxidant activity

Cite This Article: Nabil Qaid M. Al-Hajj, Algabr MN, Khamis Ali Omar, and Hongxin Wang, "Anticancer, Antimicrobial and Antioxidant Activities of the Essential Oils of Some Aromatic Medicinal Plants (Pulicaria inuloides-Asteraceae)." Journal of Food and Nutrition Research, vol. 5, no. 7 (2017): 490-495. doi: 10.12691/jfnr-5-7-6.

\section{Introduction}

Cancer is the second leading cause of death worldwide. Breast cancer accounts for $30 \%$ of all cancers, and is the primary cause of cancer-related mortality, in women [1]. A major problem with current cancer treatment is the severe lack of effective anti-tumor drugs [2]. Due to multiple side effects and problems related to common cancer treatments such as chemotherapy, surgery, and radiotherapy, alternative treatments are frequently investigated [3].

Natural products, especially plants, have played a significant role in the treatment and prevention of human diseases, worldwide and for thousands of years [4]. Plants are rich sources of chemically diverse compounds, and have properties that are beneficial to human health. Some medicinal plants have shown promising activity against various types of cancer. About $50 \%$ of known anticancer therapeutic agents are derived from plants [7]. For example, compounds such as taxol and vinca alkaloids act to destabilize the microtubules of cancer cells and prevent the rapid proliferation of tumors [8].

The application of medicinal plants often involves the use of their essential oils. Essential oils are complex mixtures of many different aromatic compounds and the composition of the oils is dependent on the genetic make-up of each cultivar, although it can also be influenced by the distillation process [11]. In the last two decades, there has been increasing interest in the pharmacological activities of essential oils [5]. Several studies on essential oils have revealed anti-cancer properties due to the presence of a variety of biologically active components [6].

Pulicaria inuloides (family Asteraceae, tribe Inuleae) is a well-known Yemeni medicinal plant [11]. There have been many studies on the applications of $P$. inuloides essential oil (PiEO) and on its anticancer, antispasmodic, anti-inflammatory, anti-diabetic, antibacterial and antioxidant activities [11,14]. However, there are no reports on the inhibition of cancer cell proliferation by PiEO. Therefore, in this study, we investigated the cytotoxic effects of PiEO on MCF-7 cells, a breast cancer cell line isolated from a 69-year-old Caucasian woman in 1970 that is widely used in studies of tumor biology and hormone mechanisms of action [1].

\section{Materials and Methods}

\subsection{Plant Material}

$P$. inuloides leaves were collected in 2016 during the flowering season (August-September) from Bany Matar, a mountainous region located northwest of Sana'a city, 
Yemen, at $15^{\circ} 21.1217^{\prime} \mathrm{N}, 44^{\circ} 12.4474^{\prime} \mathrm{E}, 2,200 \mathrm{~m}$ above sea level. Botanical identification was made by Prof. Dr. Abdellah Amine (College of Agriculture, Sana'a University). The leaves were dried for 10 days at room temperature $\left(23-25^{\circ} \mathrm{C}\right)$ in a shaded place and milled using an electrical mill. The powdered samples were stored in a dry, cool, dark place.

\subsection{Isolation of the Essential Oil}

Essential oil was obtained from $P$. inuloides leaves (500 g) by subjecting them to hydro-distillation for $6 \mathrm{~h}$ in a Clevenger apparatus according to the methods outlined by the British Pharmacopeia [15]. The oil was dried over anhydrous sodium sulfate and then stored at $4{ }^{\circ} \mathrm{C}$ prior to cell analysis. The extraction yield was calculated as the ratio of the weight of the oil to the weight of the leaves, using the following equation:

$$
\% \text { yield of oil }=\frac{\text { Weight of oil }}{\text { Weight of dried leaves }} \times 100 \text {. }
$$

\subsection{Chemicals}

All chemicals and solvents used were of analytical grade. 2, 2-diphenyl-1,1-picrylhydrazyl (DPPH), 2,6-bis(1,1-dimethylethyl)-4-methylphenol (butylated hydroxytoluene; BHT), and 2-(1,1-dimethylethyl) were obtained from TCI Europe N.V. (Zwijndrecht, Belgium). Nutrient Broth and Nutrient Agar were procured from Sinopharm Chemical Reagent Co. Ltd. (SCR; Shanghai, China). Penicillin was from AMRESCO Life Science Research Products through VWR Co., Ltd. (Shanghai, China).

\subsection{Anti-pathogenic Bacterial Activity}

\section{Pathogenic bacterial strains}

Anti-pathogenic bacterial activity was tested against six Listeria species: L. monocytogenes ATCC 7644, L. innocua ATCC 33090, L. ivanovii ATCC 19119, L. seeligeri SLCC 3954, L. welshimeri ATCC 35897, and L. grayi ATCC 25923, purchased from the China General Microbiological Culture Collection Center (Beijing, China). All strains were first identified and then cultured in sterile test tubes containing nutrient broth and incubated for $24 \mathrm{~h}$ at $37^{\circ} \mathrm{C}$. Suspensions were prepared in sterile deionized distilled water with a density of McFarland standards (0.5) to obtain a bacterial concentration of about $1.5 \times 10^{6}$ colony-forming units $(\mathrm{CFU}) / \mathrm{mL}$. The anti-pathogenic bacterial activity of PiEO was assessed at a concentration of $20 \mu \mathrm{L}$ using the agar disk diffusion method described by [11], taking into consideration the proposed amendments by [11].

\section{Agar disk diffusion}

Sterile nutrient agar was prepared according to the manufacturer's specifications and autoclaved at $121^{\circ} \mathrm{C}$ under $15 \mathrm{lbs}$ of pressure for $20 \mathrm{~min}$. After cooling, the sterile media was poured into sterile petri dishes $(90 \mathrm{~mm}$; $20 \mathrm{~mL} /$ dish). Bacterial suspensions $\left(100 \mu \mathrm{L} ; 1.5 \times 10^{8}\right.$ $\mathrm{CFU} / \mathrm{mL}$ ) were spread onto the plates. PiEO was mixed with $1 \mathrm{~mL}$ of dimethyl sulphoxide (DMSO) at different concentrations (5 mg/mL); then, $50 \mu \mathrm{L}$ was loaded onto 6-mm diameter sterile filter paper discs and individually impregnated on the surface of the poured media in the culture plates. The inoculated plates were incubated for 24 $\mathrm{h}$ at $37^{\circ} \mathrm{C}$. Penicillin $(20 \mu \mathrm{g} / \mathrm{mL})$ was used as a positive control. All experiments were performed in triplicate and the anti-pathogenic bacterial activity of PiEO was measured as the diameter of the inhibition zones (DIZ) in $\mathrm{mm}$.

\section{Determination of minimal inhibitory concentration (MIC)}

The MIC of the essential oil was determined using the microtiter broth microdilution assay described by [11] The essential oils were diluted to $50 \mu \mathrm{L} / \mathrm{mL}$ and subjected to serial dilution in a microtiter plate containing tryptic soy agar. The bacterial and yeast strains were suspended in liquid culture medium at a final concentration of $10^{4}$ $\mathrm{CFU} / \mathrm{mL}$. After incubation at $37^{\circ} \mathrm{C}$ for $24 \mathrm{~h}$, optical density was measured at $520 \mathrm{~nm}$ using a spectrophotometer. MIC was defined as the lowest concentration of the essential oil at which the microorganisms did not exhibit visible growth.

\section{Free radical-scavenging effect of PiEO}

The free radical-scavenging effects of PiEO were measured according to DPPH free radical-scavenging activity (DPPH*) as described previously [11], with slight modification. Briefly, $20 \mu \mathrm{L}$ of each PiEO treatment was mixed with $3.5 \mathrm{~mL}$ of $\mathrm{DPPH}^{*}$ methanolic solution $(6 \times$ $10^{5} \mathrm{Mol} / \mathrm{L}$ ). The mixture was allowed to react in the dark at room temperature. Then, the absorbance was measured after $30 \mathrm{~min}$ at $517 \mathrm{~nm}$, and converted to DPPH* \% by the following equation (Eq. 2):

$$
\mathrm{DPPH}=[(\mathrm{A} 0-\mathrm{A} 1) / \mathrm{A} 0] \times 100 .
$$

where A0 is the absorbance of the control and A1 is the absorbance of the targeted treatment. BHT was used as a positive control at $120 \mathrm{mg} / \mathrm{L}$. All treatments were carried out in triplicate.

\section{Cancer Cell Lines}

The MCF-7 human breast cancer cell line frozen in liquid nitrogen $\left(-80^{\circ} \mathrm{C}\right)$ was obtained from the Type Culture Collection of the Chinese Academy of Sciences (Shanghai, China). 9.4.6.

\section{Cell culture media RPMI 1640 proportions}

Roswell Park Memorial Institute culture medium 1640 (RPMI 1640) powder was added into water and stirred until completely dissolved; then, $2 \mathrm{~g} / \mathrm{L}$ sodium bicarbonate was added and dissolved completely to the desired $\mathrm{pH}$ ( $\mathrm{pH}$ 7.0-7.2). The media was filtered immediately under sterile conditions.

\section{Cell culture}

MCF-7 cells were used for the cytotoxicity assay. All cancerous cell lines were grown in RPMI 1640 media supplemented with $10 \%$ fetal bovine serum (FBS, SigmaAldrich, St. Louis, MO, USA) and antibiotics: a mixture of streptomycin $(50 \mu \mathrm{g} / \mathrm{ml})$ and penicillin $(50 \mathrm{UI} / \mathrm{mL})$. The cancer cell line was maintained at $37^{\circ} \mathrm{C}$ in an atmosphere of $5 \% \mathrm{CO}_{2}$ and $95 \%$ air (100\% humidity). At $70-80 \%$ confluence, cells were detached from culture flasks by treatment with $0.05 \%$ trypsin-EDTA. The cells were counted, and their viability determined, using trypan blue exclusion dye (Sigma-Aldrich) on a hemocytometer (Boeckel \& Co., GmbH, Hamburg, Germany). After 
counting, cultures were diluted in 96-well tissue culture plates to obtain the required cell density.

\section{Cell subculture}

The cells were placed immediately in a $37^{\circ} \mathrm{C}$ water bath for rapid thawing, and then transferred to $15 \mathrm{~mL}$ tubes with culture media followed by centrifugation at 1,000 rpm for 5 min. Fresh RPMI 1640 media was placed into the flasks. Supernatant was aspirated off the centrifuged cells, and an appropriate volume of fresh culture medium was added to each well of cells by pipetting. An aliquot of cells was transferred to new culture containers according to the recommended ratio of the cell line. The cells were observed under a microscope before incubation at $37^{\circ} \mathrm{C}$.

\section{Cytotoxicity assay}

3-(4, 5-dimethylthiazol- 2-yl)-2, 5-diphenyltetrazolium bromide (MTT) was used to assess cytotoxic activity [16]. MCF-7 cell suspensions $\left(100 \mu \mathrm{L} ; 1.0 \times 10^{4}\right.$ cells/mL) were added to 96-well plates and incubated for $24 \mathrm{~h}$ at $37^{\circ} \mathrm{C}$ under a $5 \% \mathrm{CO}_{2} / 95 \%$ air (100\% humidity) atmosphere in an incubator, to allow stabilization before adding extracts. The cells were then treated with PiEO dissolved in DMSO to a final concentration of $0.5 \%$ in the culture media and incubated for $48 \mathrm{~h}$, then fixed by adding $50 \mu \mathrm{L} /$ well cold $50 \%(\mathrm{w} / \mathrm{v})$ trichloroacetic acid (TCA) to a final concentration of $10 \%$ in the culture media and incubated for $1 \mathrm{~h}$ at $4^{\circ} \mathrm{C}$. After $48 \mathrm{~h}$, the media was removed and the cells were washed with distilled water.

\section{Morphological examination}

To observe morphological changes, about $1 \times 10^{4}$ cells were cultured in 96-well plates, allowed to adhere overnight, and then treated with various concentrations of PiEO for 24, 48 and $72 \mathrm{~h}$. After the treatment period, the cells were washed twice with phosphate-buffered saline (PBS) and then observed and photographed under an inverted microscope.

\subsection{Statistical Analysis}

Data were subjected to analysis of variance (ANOVA) following a completely random design to determine the least significant difference (LSD) at $P<0.05$ using SPSS software (ver. 11.5; SPSS, Inc., Chicago, IL, USA). Cytotoxicity analyses were performed in triplicate.

\section{Results}

\subsection{Antimicrobial Activity of PiEO}

The bacteriostatic activity of PiEO showed pronounced activity against all of the Listeria spp. tested in this study, as assessed by the disc diffusion assay. In addition, MIC was assessed by the microtiter broth microdilution assay (Table 1).

Table 1. Diameter of the inhibition zone of $P$. inuloides essential oil (PiEO) compared to antibiotics

\begin{tabular}{lccc}
\hline \multicolumn{4}{c}{ Inhibition zone diameter $^{\mathrm{a}}(\mathrm{mm})$} \\
\hline Pathogen bacterial strains & $\begin{array}{c}\text { PiEO } \\
(20 \mathrm{mg} / \mathrm{mL})\end{array}$ & $\begin{array}{c}\text { Penicillin } \\
(20 \mu \mathrm{g} / \mathrm{mL})\end{array}$ & $\begin{array}{c}\text { MIC } \\
(\mu \mathrm{g} / \mathrm{ml})\end{array}$ \\
\hline L. monocytogenes & $15 \pm 0.8$ & $20 \pm 0.2$ & 5.49 \\
L. innocua & $15 \pm 0.2$ & $20 \pm 0.7$ & 5.49 \\
L, ivanovii & $13 \pm 0.8$ & $18 \pm 0.8$ & 5.49 \\
L. seeligeri & $13 \pm 0.4$ & $14 \pm 0.5$ & 11.55 \\
L. welshimeri & $15 \pm 0.3$ & $16 \pm 0.2$ & 6.24 \\
L. grayi & $15 \pm 0.5$ & $19 \pm 0.3$ & 6.24 \\
\hline
\end{tabular}

${ }^{\mathrm{a}} \mathrm{DIZ}$, diameter of inhibition zone (mm) including disk diameter (6 mm).

\subsection{Free Radical Scavenging Effect}

The antioxidant activity of PiEO was determined by the $\mathrm{DPPH}$ free radical scavenging assay. The DPPH scavenger effect (DPPH-Pi) assay depends on the existence of natural phenols and their ability to donate a hydrogen ion to convert stable free radicals (DPPH) to non-radicals (DPPH-H). The results are presented in Figure 1.

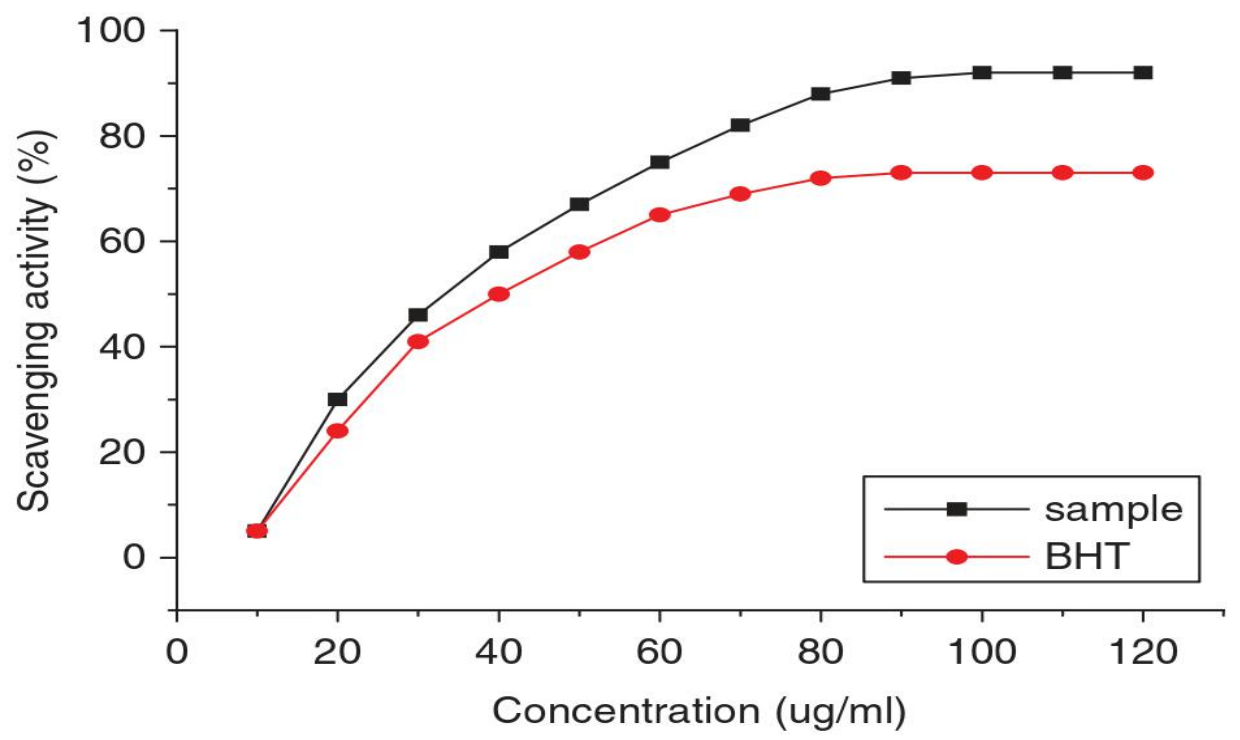

Figure 1. DPPH radical scavenging activity of Pulicaria inuloides essential oil (PiEO) versus butylated hydroxytoluene (BHT) (Each value represents mean \pm standard deviation $(\mathrm{SD})(\mathrm{n}=3)$.) 


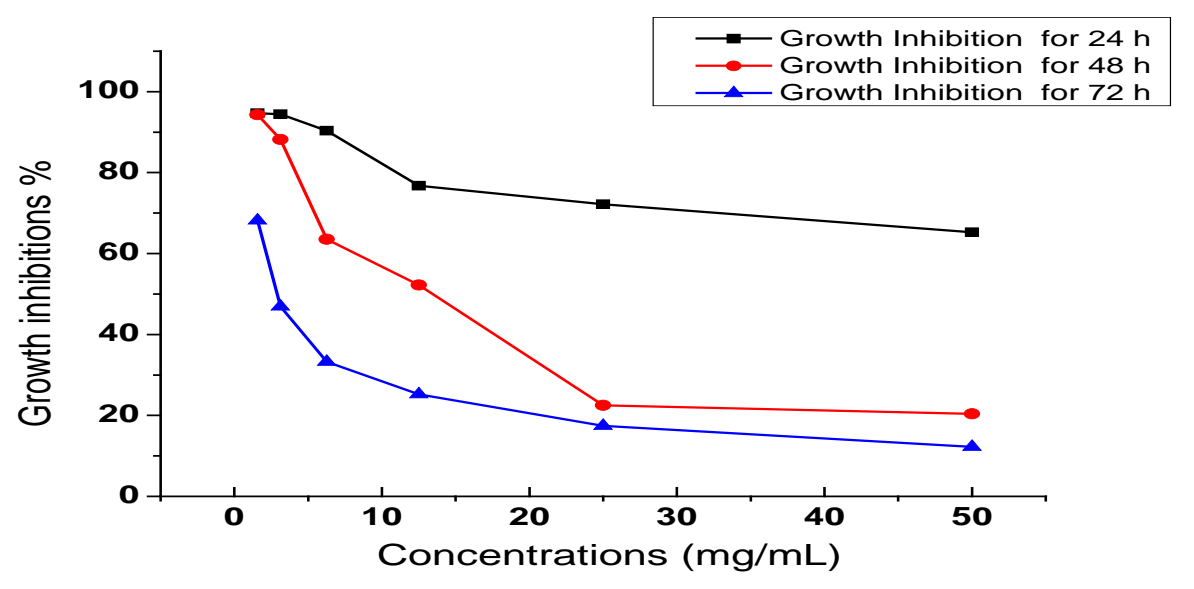

Figure 2. Percentage growth inhibition of MCF-7 cells by PiEO.

\subsection{Cytotoxic Activity of PiEO on MCF-7 Cells}

PiEO showed significant cytotoxic activity against the MCF-7 cells used in the study. The results are given in Table 2 and Figure 2.

Table 2. The cytotoxic activity of $P$. inuloides essential oil (PiEO) on MCF-7 cells

\begin{tabular}{cccc}
\hline Concentration $(\mathrm{mg} / \mathrm{mL})$ & MTT1 (24h) & MTT2 (48h) & MTT3 (72) \\
\hline Control & 100 & 100 & 100 \\
1.56 & $65.25 \pm 5.07^{\mathrm{e}}$ & $20.40 \pm 1.11^{\mathrm{d}}$ & $12.21 \pm 1.11^{\mathrm{e}}$ \\
3.125 & $72.15 \pm 2.53^{\mathrm{d}}$ & $22.48 \pm 0.60^{\mathrm{d}}$ & $17.41 \pm 2.35^{\mathrm{e}}$ \\
6.25 & $76.74 \pm 0.76^{\mathrm{c}}$ & $2.19 \pm 1.18^{\mathrm{c}}$ & $25.22 \pm 1.43^{\mathrm{d}}$ \\
12.5 & $90.33 \pm 0.91^{\mathrm{b}}$ & $63.54 \pm 1.11^{\mathrm{b}}$ & $33.22 \pm 1.47^{\mathrm{c}}$ \\
25 & $94.40 \pm 0.31^{\mathrm{a}}$ & $88.18 \pm 2.99^{\mathrm{a}}$ & $46.92 \pm 2.25^{\mathrm{b}}$ \\
50 & $94.67 \pm 0.76^{\mathrm{a}}$ & $94.28 \pm 1.3^{\mathrm{a}}$ & $68.91 \pm 6.29^{\mathrm{a}}$ \\
IC50 & -- & IC $_{50}=3.0$ & IC $_{50}=12.9$ \\
\hline
\end{tabular}

Different letters indicate significant differences between PiEO and MTT $(\mathrm{p}<0.05)$. Results are expressed as means \pm SD.

\subsection{Morphological Analysis}

Morphological analysis of MCF-7 cells was carried out to gain insight into morphological alterations caused by treatment with PiEO. Untreated MCF-7 cells were spherical in shape. The nuclei and nucleoli and were larger than those of the treated cells (Figure 3). Our study showed to cells treated by $6.25,12.5,25.0$ and $50.0 \mu \mathrm{l} / \mathrm{ml}$ oil had become vacuolated and shrunken and some cells were death in $24 \mathrm{~h}$ and $48 \mathrm{~h}$ while cells treated in the same concentrations at $72 \mathrm{~h}$ was begin to growth and increased.

\section{Discussion}

\subsection{Antimicrobial Activity of PiEO}

The in vitro anti-pathogenic bacterial effect of PiEO was assessed and the results are presented in Table 1 . There was a positive relationship between PiEO concentration and DIZ. All DIZ values less than $10 \mathrm{~mm}$ were ignored. The results also demonstrated that PiEO had noticeable activity against all species of Listeria. There were no significant differences in the DIZ induced by treatment with $20 \mathrm{mg} / \mathrm{mL}$ PiEO for L. monocytogenes, L. grayi, L. welshimeri, and L. innocua. The DIZs induced by $20 \mathrm{mg} / \mathrm{mL} \mathrm{PiEO}$ were comparable to those induced by $20 \mu \mathrm{g} / \mathrm{mL}$ penicillin. While the antimicrobial activity of PiEO has been reported previously, with DIZs against S. aureus, S. pneumonia and B. subtilis of 16.6, 18.2 and $18.0 \mathrm{~mm}$, respectively [11], our current study is the first to report the antibacterial activity of PiEO against Listeria. The MIC values indicate that PiEO has a greater inhibitory action against all Listeria strains (Table 1). The Gram-positive strains were less sensitive to inhibition than the Gram-negative strain. This variation in inhibition may be attributed to the bacterial cell membrane constituents. The cell membranes of Grampositive bacteria contain an outer peptidoglycan layer, which is an ineffective permeability barrier, while the cell membranes of Gram-negative bacteria contain a more effective permeability barrier in the outer membrane consisting of lipopolysaccharides. [11]

\subsection{Free Radical-scavenging Effects}

Antioxidant ability is most commonly determined by the $\mathrm{DPPH}^{*}$ scavenging activity assay [18] because of its simplicity and accuracy. The $\mathrm{DPPH}^{*}$ scavenging assay is based on the presence of natural phenolic compounds and their ability to donate a hydrogen ion to convert stable free radical $\mathrm{DPPH}^{*}$ to a non-radical state, DPPH-H. The stability of $\mathrm{DPPH}^{*}$ is primarily due to steric crowding around the divalent nitrogen atom [19]. This change depends on the number of hydrogen atoms absorbed, which can be monitored spectrophotometrically by measuring the bleaching of $\mathrm{DPPH}^{*}$ color from purple to yellow [20]. Figure 1 shows that PiEO was more active than $\mathrm{BHT}$ in converting $\mathrm{DPPH}^{*}$, with $\mathrm{PiEO}$ converting $55-98 \%$ while BHT converted 50-80\%. The ability of $\mathrm{PiEO}$ to quench hydroxyl radicals, which are implicated in some diseases, revealed the presence of antioxidant compounds in this plant [16].

\subsection{Cytotoxic Activity of PiEO on MCF-7 Cells}

The results for growth inhibition of MCF-7 cells by various concentrations of PiEO are shown in Table 2. There significant differences between all the Times (24h, 
$48 \mathrm{~h}$ and 72 hours. The values in $24 \mathrm{~h}$ and $48 \mathrm{~h}$ were the better than 72 hours. In concentrations $50 \mu \mathrm{l} / \mathrm{ml}$ oil, the values were 94.67, 94.28 and $68.91 \mu \mathrm{l} / \mathrm{ml}$ in all times tested respectively Table 2 . In the present study, the growth of MCF-7 was inhibited by PiEO treatment in a dose-dependent manner (Figure 2). The 50\% cytotoxic effect $\left(\mathrm{IC}_{50}\right)$ of PiEO was found to be 12.9 and $3.0 \mu \mathrm{l} / \mathrm{mL}$. In our study, PiEO showed broad spectrum cytotoxicity, with a prominent effect on MCF-7 breast carcinoma cells at high concentrations. $\mathrm{PiEO}$ treatment significantly decreased the growth rate of MCF-7 cells compared with controls. This may be attributable to isothiocyanates (ITCs), which have been reported to be important and promising chemopreventive compounds [17]. The essential oil of $P$. jaubertii from southern Saudi Arabia had a higher proportion of carvotanacetone (98.6\%), and showed

(1)

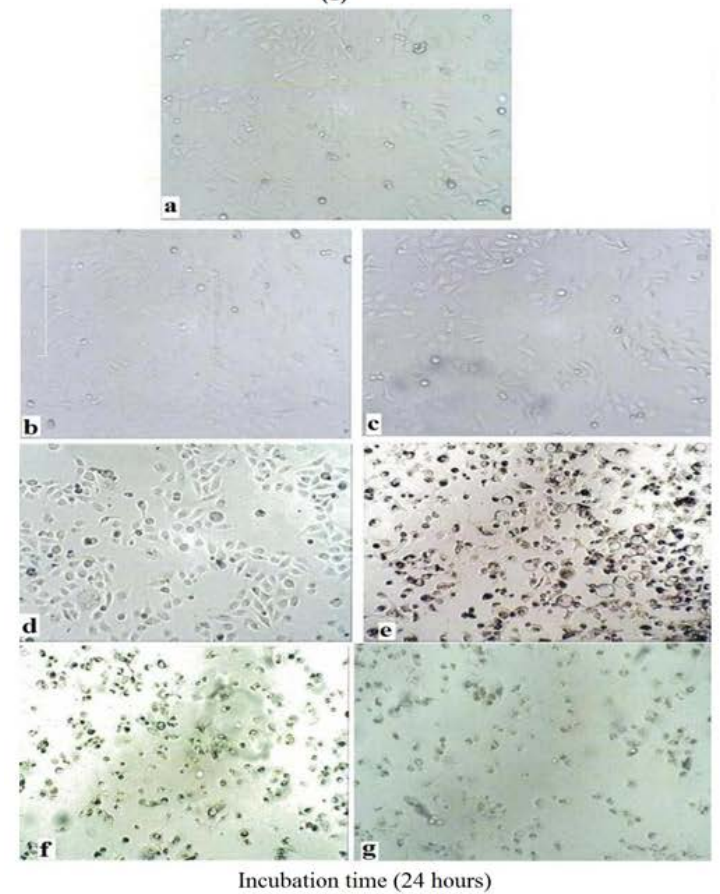

excellent in vitro cytotoxic activity against MCF-7 and Hep-G2 cells $\left(\mathrm{IC}_{50}=3.8\right.$ and $5.1 \mu \mathrm{l} / \mathrm{mL}$, respectively) [17]. In recent years, numerous investigations have shown that sulfur-containing compounds induce apoptosis in multiple cell lines (including breast and colorectal cell lines) and animal models [18]. In this study, PiEO significantly inhibited growth in an MCF-7 cell line at high $\mathrm{IC}_{50}$ values (Table 2). An $\mathrm{IC}_{50}$ of an oil extract less than $100 \mathrm{~g} / \mathrm{mL}$ is categorized as a potentially cytotoxic substance [18]. In previous investigations of PiEO on MCF-7 cells, the $\mathrm{IC}_{50}$ was $5.36 \mu \mathrm{g} / \mathrm{mL}$ [19]. In the present study, PiEO was found to be cytotoxic towards human MCF-7 cells in an MTT assay, and the concentrations required for $50 \%$ cell death were 12.9 and $3.0 \mathrm{mg} / \mathrm{mL}$. Hence, our study shows the efficacy of PiEO against MCF-7 cells, suggesting a protective effect against breast cancer.

(2)

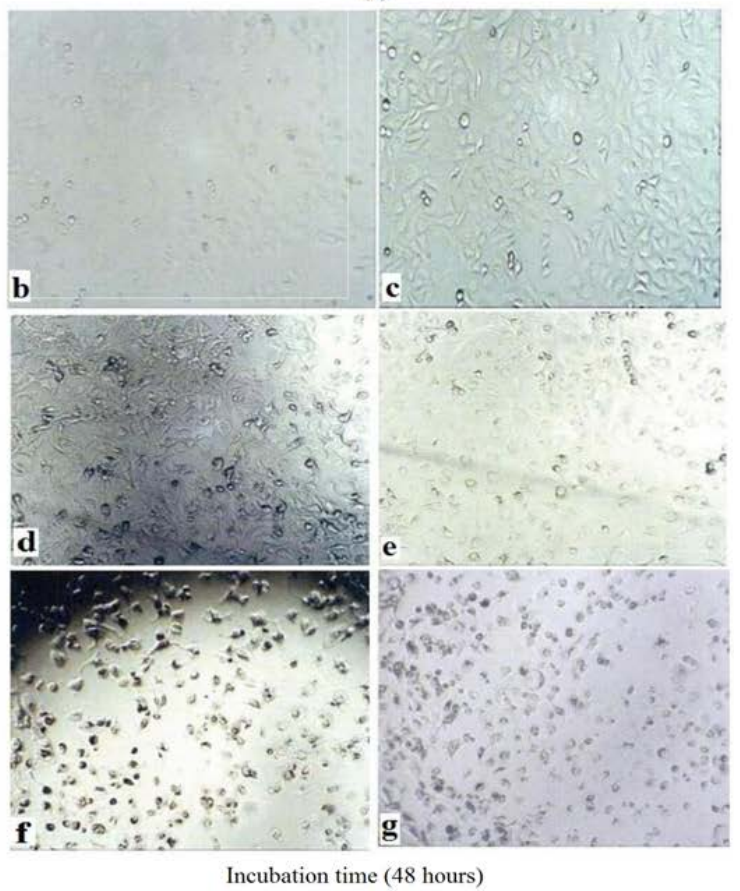

(3)

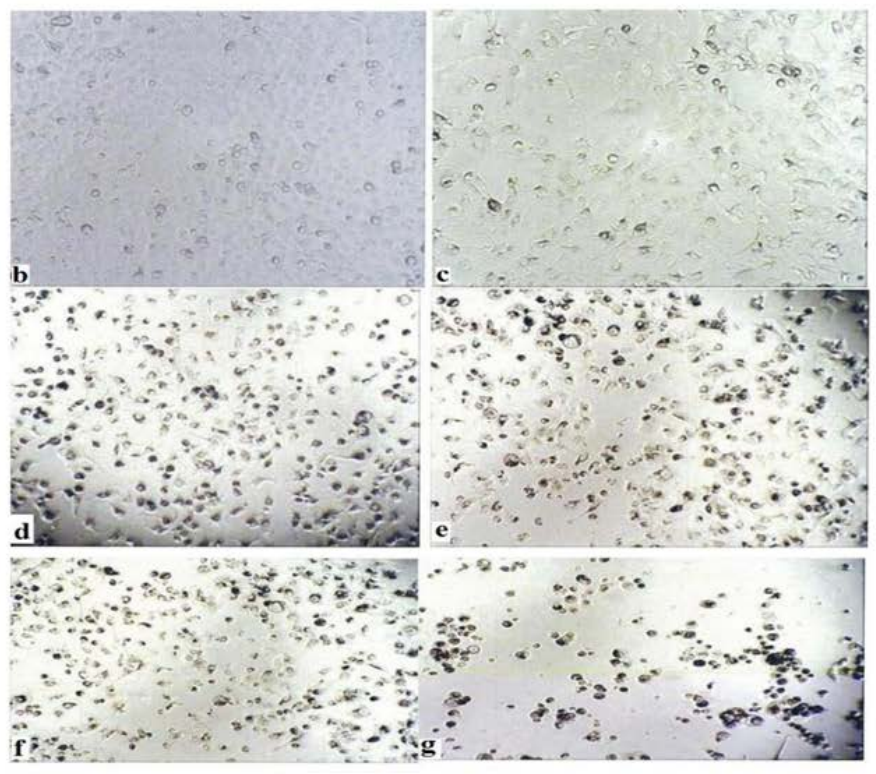

Incubation time ( 72 hours)

Figure 3. Morphological changes to the MCF-7 cells treated with PiEO at a (control-untreated ), b (1.65), c (6.25), d (12.5), f (25) and g (50) after 24, 48 and 72 h incubation. (1) =24 hours, (2) =48 hours and (3) = 27 hours incubation 


\subsection{Morphological Analysis}

Cells incubated with 1.56 and $3.125 \mathrm{mg} / \mathrm{mL}$ PiEO for $24 \mathrm{~h}$, and $1.56 \mathrm{mg} / \mathrm{mL}$ for $48 \mathrm{~h}$, showed the characteristic morphological changes of apoptosis, including membrane blebbing, chromatin condensation, and the formation of apoptotic bodies. The cell shrinkage increased progressively in a dose- and time-dependent manner. This shrinkage may have been due to the growth-inhibiting effects of some bioactive compounds of PiEO (Figure 3). Interestingly, in this study, treating cancer cells with PiEO produced a significant dose-dependent decrease in cell viability as measured by the MTT assay. A significant decrease was seen in cell viability at multiple concentrations of PiEO. Cells on the control plate did not show any morphological changes, and were irregular, confluent aggregates with rounded and polygonal cell morphology (intact).

A previous toxicology study focused on the effects of PiEO on breast cancer [20]. However, various bioactive compositions of $P$. inuloides may be attributed to synergy between a number of secondary metabolites, including citrinin, monacolin $\mathrm{K}$, dimerumic acid, flavonoids, total phenols, and other compounds. On the other hand, the percentage of viable cells in cell lines increased with increasing treatment duration. These results were similar to studies on the cytotoxic effects of goniothalamin on human breast cancer cells [20].

\section{Conclusion}

PiEO exerted a strong antimicrobial action against all tested strains of Listeria. This study also showed that PiEO possessed strong antioxidant activity and effective cytotoxic activity against MCF-7 cells. These properties are likely to be related to the oil constituents. Our findings suggest that PiEO has potential as an inexpensive and easily accessible natural anti-cancer agent, as a novel broad-spectrum bioactive compound.

\section{Acknowledgments}

This work was supported by the National Science and Technology Program of China (grant no. 2014BAD33B05). The authors thank the students at the Nutrition Laboratory of the School of Food Science and Technology at Jiangnan University (Jiangnan, China) for their technical assistance.

\section{References}

[1] Coleman, W. B., \& Tsongalis, G. J. (Eds.). (2001). The molecular basis of human cancer. Springer Science \& Business Media.

[2] Rezaie-Tavirani, M., Fayazfar, S., Heydari-Keshel, S., Rezaee, M. B., Zamanian-Azodi, M., Rezaei-Tavirani, M., \& Khodarahmi, R.
(2013). Effect of essential oil of Rosa Damascena on human colon cancer cell line SW742.Gastroenterology and Hepatology from bed to bench, 6 (1), 25.

[3] Chin, Y. W., Balunas, M. J., Chai, H. B., \& Kinghorn, A. D. (2006). Drug discovery from natural sources. The AAPS journal, 8 (2), E239-E253.

[4] Kinghorn, A. D. E. A., Farnsworth, N., Soejarto, D., Cordell, G., Swanson, S., Pezzuto, J., \& Wild, R. (2003). Novel strategies for the discovery of plant-derived anticancer agents. Pharmaceutical Biology, 41 (sup1), 53-67.

[5] Kulisic-Bilusic, T., Schmöller, I., Schnäbele, K., Siracusa, L., \& Ruberto, G. (2012). The anticarcinogenic potential of essential oil and aqueous infusion from caper (Capparis spinosa L.). Food chemistry, 132(1), 261-267.

[6] Sylvestre, M., Pichette, A., Longtin, A., Nagau, F., \& Legault, J. (2006). Essential oil analysis and anticancer activity of leaf essential oil of Croton flavens L. from Guadeloupe. Journal of Ethnopharmacology, 103(1), 99-102.

[7] Balunas, M. J., \& Kinghorn, A. D. (2005). Drug discovery from medicinal plants. Life sciences, 78(5), 431-441.

[8] Prasain, J. K., \& Barnes, S. (2007). Metabolism and bioavailability of flavonoids in chemoprevention: current analytical strategies and future prospectus. Molecular pharmaceutics, 4(6), 846-864.

[9] Ali, M. S., Saleem, M., Ali, Z., \& Ahmad, V. U. (2000). Chemistry of zataria multiflora (lamiaceae). Phytochemistry, 55(8), 933-936.

[10] Prasain, J. K., \& Barnes, S. (2007). Metabolism and bioavailability of flavonoids in chemoprevention: current analytical strategies and future prospectus. Molecular pharmaceutics, 4(6), 846-864.

[11] Al-Hajj, N. Q. M., Wang, H. X., Ma, C., Lou, Z., Bashari, M., \& Thabit, R. (2014). Antimicrobial and antioxidant activities of the essential oils of some aromatic medicinal plants (Pulicaria inuloides-Asteraceae and ocimum forskolei-Lamiaceae). Tropical Journal of Pharmaceutical Research, 13(8), 1287-1293.

[12] Sousa, A. C., Gattass, C. R., Alviano, D. S., Alviano, C. S., Blank, A. F., \& Alves, P. B. (2004). Melissa officinalis L. essential oil: antitumoral and antioxidant activities. Journal of pharmacy and pharmacology, 56(5), 677-681.

[13] WANG, J. R., MA, D. W., \& TANG, L. (2009). Allelopathy of volatile oil from Chenopodium ambrosioides L. on receptors [J]. Southwest China Journal of Agricultural Sciences, 3, 054.

[14] Khuzwayo, J. K. (2011). Khuzwayo, J. K. (2011). Essential oil composition and some biological activities of tetradenia riparia (Doctoral dissertation, University of Zululand).

[15] Othman, M., San Loh, H., Wiart, C., Khoo, T. J., Lim, K. H., \& Ting, K. N. (2011). Optimal methods for evaluating antimicrobial activities from plant extracts. Journal of Microbiological Methods, 84(2), 161-166.

[16] Tohidi, B., Rahimmalek, M., \& Arzani, A. (2017). Essential oil composition, total phenolic, flavonoid contents, and antioxidant activity of Thymus species collected from different regions of Iran. Food Chemistry, 220, 153-161.

[17] Oliveira, G. K., Tormin, T. F., Sousa, R. M., de Oliveira, A., de Morais, S. A., Richter, E. M., \& Munoz, R. A. (2016). Batch-injection analysis with amperometric detection of the DPPH radical for evaluation of antioxidant capacity. Food chemistry, 192, 691-697.

[18] Foti, M. C. (2015). Use and Abuse of the DPPH• Radical. Journal of agricultural and food chemistry, 63(40), 8765-8776.

[19] Algabr, M. N., Mekkiou, R., Ameddah, S., Menad, A., Boumaza, O., Seghiri, R., ... \& Benayache, F. (2010). Antioxydant activities from the aerial parts of Pulicaria jaubertii. Advances in Natural and Applied Sciences, 4(1), 63-71.

[20] Al-Hajj, N. Q. M., Wang, H., Gasmalla, M. A., Ma, C., Thabit, R., Rahman, M. R. T., \& Tang, Y. (2014). Chemical composition and antioxidant activity of the essential oil of Pulicaria inuloides. Journal of Food and Nutrition Research, 2 (5), 221-227. 